\title{
LIBRARY POWER AS A VEHICLE FOR THE EVOLUTION OF CHANGE
}

\author{
Shirley Tastad \\ MSIT Department \\ Georgia State University \\ University Plaza, Atlanta GA 30303 USA \\ E-mail: stastad@gsu.edu.us \\ Julie Tallman \\ Department of Instructional Technology \\ University of Georgia, USA
}

\section{DEDICATION}

This paper is dedicated to the memory of Dr. Rebecca Smith, who died on the first day of Spring, 1997. She was a friend, colleague, and mentor, who embodied the quote, "vision with action can change the world." She changed the world of those she touched. May her role as principal serve as an exemplar of leadership in educational reform.

\begin{abstract}
This paper reports research based on an ongoing three-year investigation of changes that have taken place in two Library Power schools in a large urban school system in the south-eastern United States.

In the coming year, a new set of national guidelines for school library media specialists will be published (Stripling, 1996a). The document will emphasize the intersection of educational reform efforts and the crucial role of the school library media specialist. Barron and Bergen (1992) have emphasized that school library programs could be one of the most dynamic elements in school restructuring. In the past, school library programs that prepared students to be information literate citizens of the future focused on the following:
\end{abstract}

providing in-depth learning experiences; emphasizing thinking and inquiry skills; fostering a community of learners; providing an atmosphere in which students felt safe and successful; helping students create authentic assessment products; making students responsible for their own learning; and teaching through coaching. (Stripling, 1996c, p. 636)

Drafts of the new guidelines (Stripling, 1996a) emphasize constructivist theories of learning (Pitts, 1994, 1995). School libraries of the future will be learning-centered libraries, encouraging students to take responsibility to become lifelong learners who contribute to the learning community. The DeWitt Wallace-Readers Digest Library Power Initiative (see American Association of School Librarians, 1995) has been instrumental in precipitating reform efforts in school libraries.

Educational reform hinges on improving student learning; quality school library media programs are integral to high quality education. The philosophical emphasis of library media programs shifted from an early focus on collection to program to instruction and finally to studentcentered learning (Stripling, 1996b). This evolution of thought parallels the philosophical changes that have occurred in systemic reform efforts throughout the country.

National Library Power programs have strengthened the role of the school library media specialist and the school library program. The initiative emphasizes that library media specialists integrate information literacy skills throughout the curriculum. Library Power has attempted to change the perceived role of the media specialist as a "keeper of the books" to that of teaching partner, leader, and advocate for student achievement. In Library Power schools, principals, library 
media specialists, teachers, students, parents, and the community assume significant roles in the evolution of change.

Educational reform has focused on connecting students with the future, a world in which information literacy skills will be survival skills. Researchers discussed the difficulties school systems experience when implementing systemic change. (see, for example, Fullan, 1996; Saracen, 1996; Zakariya, 1996) Stakeholders often feel burdened with new responsibilities, fragmented and unprepared to meet the challenges, reducing their motivation to participate in reform efforts.

Sarason (1996) indicated that there are interrelated reasons why efforts for systemic reform in schools have met with dissatisfaction. Reformers fail to examine the total picture of the school, which never exists in an encapsulated environment. Reformers have not confronted the concept that school systems are a derivative of our socialization into society and existing culture; "insiders" and "outsiders" paradoxically hold the same views of what is and should be, because they are all products of the same school culture; schools and school systems should be judged with a view of the past; and to understand the psychology of change in schools, one cannot merely focus on the psychology of individuals but must examine the entire system.

Educational systems, because of their inherent nature, are more apt to maintain the status quo rather than to change themselves. In order to achieve systemic reform, strategies must be discovered to motivate large numbers of stakeholders to focus on developing the change. In sum, "you cannot improve student learning for all or most students without improving teacher learning for all or most teachers." (Fullan, 1996, p. 423)

The researchers examined how the Library Power initiative in two schools reflected educational reform efforts at a systemic level. As participant observers, constant comparisons allowed recording of struggles to achieve Library Power goals and provided valuable insight into the evolutionary process of change. Change takes time; Library Power improves student learning by improving teacher, principal, media specialist, parent, and community learning.

\section{METHOD}

\section{National Library Power Program}

The National Library Power Program, initiated in 1988, now includes 19 participating sites and over 700 schools throughout the United States. The $\$ 45$ million initiative, supported by DeWitt Wallace-Reader's Digest Fund, is promoted and directed in collaboration with the American Association of School Librarians (AASL).It was designed to improve the teaching and learning process in elementary and middle schools through improved school library media centers. Participating school districts are required to meet stringent selection criteria, including a commitment to match Library Power dollars spent with local funds, pay for labor costs for library renovations with materials being paid for by the grant, have full time certified library media specialists in each Library Power school, and operate library media centers with a flexible schedules to allow open access to all students. In addition, the $\$ 1.2$ million, three-year implementation grant awards are administered through a Local Education Fund (LEF), which is designed to act as a bridge from the school district to local, state, and national partners (AASL, 1995; Sadowski, 1994).

Each Library Power site implements the grant in individual ways to achieve the goals of the program. As a vehicle for educational reform through the school library media center, Library Power national goals are:

- to create a national vision and new expectations for public elementary and middle school library programs and to encourage new and innovative uses of the library's physical and human resources;

- to create exemplary models of library media programs that are an integral part of the educational process;

- to strengthen the role of the librarian as a teacher, information specialist and learning facilitator who assists teachers and students in becoming effective users of ideas and information;

- to encourage collaboration among teachers, administrators and librarians that results in significant improvement in teaching and the learning process;

- to demonstrate the significant contributions that library programs can make to school 
reform and restructuring efforts;

- to encourage the creation of partnerships among leaders in school districts, public libraries, community agencies, business communities, academic institutions, and parent groups to improve and support school library programs. (AASL, 1995)

\section{PARTICIPANTS AND CONTEXT}

\section{Access to Participants}

Invited by the local Library Power director and the coordinator of media services to join the team as researchers and documentors for the grant, the study was approved through the formal district research proposal agenda to obtain official permission for access to schools and personnel. Participants were volunteers recruited at a monthly meeting of Library Power library media specialists. Although participants were reluctant to participate in a research study because of perceived substantial demands placed on them by grant personnel, the study has progressed uninterrupted through the duration of the three-year grant. In exchange for access to four Library Power schools, the researchers volunteered to participate in workshops and other staff development activities for the district.

\section{Participants and Context}

The study began in the fall of 1994 and has continued through the 1996-1997 school year, coinciding with the $\$ 1.2$ million grant from DeWitt Wallace-Readers Digest Fund. The qualitative study was initially undertaken with four elementary schools out of ten participating in the first year of the three year grant. During the second year, ten additional elementary schools were added to the round one schools. In the third year, ten elementary schools and four middle schools were added to Library Power schools for a total of 34 schools. Two schools were dropped from the study in the second year, resulting from significant changes in personnel from the first to the second year. It was decided that the study would continue with the two round one schools, without adding others to the research project.

The schools are part of a large urban school district in the southeastern United States. (Schools and participants will be identified through pseudonyms to preserve anonymity.) The population of the district of 58,739 students is 90\% African American, 6\% Caucasian, 2\% Hispanic, and $2 \%$ other. Martin Luther King, Jr. Elementary School, in a working class neighborhood, has a student population of 577 that is $66 \%$ African American, 2\% Caucasian, 8\% Hispanic, and 24\% other. Students qualifying for free lunch and reduced price lunch exceed 87\%. During the 1996-1997 school year, there was greater than a 30\% change in the student population, with many students moving to different schools and different neighborhoods.

George Washington Carver Elementary School has a student population of 486 that is $59 \%$ African American, 37\% Caucasian, 1\% Hispanic and 3\% other. The number of students qualifying for free and reduced price lunch is 54\%. Carver Elementary School is located in a middle class neighborhood with a more stable student population than King Elementary School.

The school library media specialists, Mrs. Gerrard at Carver Elementary and Mrs. Decker at King Elementary, are both nearing the end of their professional careers, having contributed more than 30 years of service to the school system. They received initial training as media specialists from library programs in the area. Both have discussed retirement in the near future, with one stating that she remained to see her school through the three-year Library Power Program.

During the time of the study, the library media center and library media programs at Carver and King have undergone dramatic changes. King school has been under constant renovation, with the students, faculty, and staff remaining in the building. King opened its new media center during the 1995-1996 school year, while parts of the school continue to undergo construction. Carver school was moved to an old abandoned high school in the neighborhood during the first two years of the Library Power project, returning to a completely renovated school including a new media center in the fall of 1996.

Both schools have experienced significant changes in technology implementation. The entire school district has been involved in automating media centers with on-line catalogs and circulation systems. The district began with automating high schools, then middle schools, and finally elementary schools. The project has been hampered with old buildings having inadequate wiring and telephone 
lines to handle the dramatic technological changes. Library media specialists were required to weed collections to prepare for the retrospective conversion of their card catalogs to on-line catalogs. To date, the project is incomplete in Carver and King schools.

Dr. Mary Jones, principal of King school will retire following the 1996-1997 school year, after a professional career exceeding 30 years. The principal of Carver school, Dr. Rebecca Smith, will continue as principal. Both individuals are highly regarded administrators in their schools and throughout the district.

\section{DATA COLLECTION AND ANALYSIS}

\section{Data Collection}

Data were collected over a three-year period beginning in the fall of 1994, including interviews with key personnel in the Library Power initiative, the coordinator of media services, the local Library Power director, library media specialists, and principals. Field notes included participant observations of interactions among teachers, media specialists, and students, focus group interviews with teachers, notes from meetings, researcher debriefing sessions, and interpretation and reflections on working hypotheses. Additional data included a variety of written documentation including collaborative planning logs and thematic units planned with teachers.

In addition, researchers collected data in the form of a survey instrument focused on collaborative planning activities of media specialists administered in November, 1996 to all Library Power schools and an equal number (30) of randomly selected elementary non-Library Power schools in the same district. All audio tapes of interviews were transcribed, printed out, and sorted to identify categories of concepts to be examined.

\section{General Data Analysis Procedures}

Phenomenological inquiry as described by Patton (1990) and Weingand (1993), guided use of observations, interviews, and written documentation to suggest working hypotheses. Continuous data analysis followed the naturalistic procedures outlined by Lincoln and Guba (1985) to allow patterns of behavior and understanding to emerge. As participant observers, the researchers' experiences were integrated with those of our co-researchers, the library media specialists. The depth, intensity, and recursive nature of our research promoted heuristic inquiry (Patton, 1990) into the nature of our experiences. The results of data collection have allowed working hypotheses to emerge and be examined (Glaser \& Strauss, 1967) about the nature of change and restructuring of school library media centers.

Originally, research focused on the collaborative planning relationships of media specialists as full members of each curriculum planning team. As hypotheses emerged from data analysis, it became apparent that media specialists played significant roles in change that occurred within the culture of the school. The media specialist, an integral participant in curriculum planning and implementation, could serve as catalyst for change within the school environment. Principals served pivotal roles in their schools, encouraging and providing opportunities for collaboration among teachers and library media specialists.

\section{RESULTS}

\section{Developing a Stronger Curricular Role for the Media Specialist}

One goal of the Library Power program has been for the media specialist to facilitate teachers and students becoming effective users of ideas and information. Resource-based learning, using a variety of information sources instead of textbooks, prepares students for lifelong learning (Breivik, 1992; Weisburg \& Toor, 1995). It involves collaboratively planned interdisciplinary units of instruction, integrating both content and information process skills (Stripling, 1996c). Resourcebased learning connects students to real life experiences, heightening the usefulness of information they gather (Glasser, 1992). Because the focus is on student learning, higher order thinking skills are required to deal with complex ideas. Students must locate and evaluate information from a variety of sources and create diverse and shared products (Weisburg \& Toor, 1995). 
In order to successfully implement resource-based teaching and learning, library collections must be relevant and current. Collections at the four schools initially participating in the Library Power program were dated and unattractive. When media specialists weeded or culled their collections, sometimes as much as $75 \%$ of the volumes, it created a dramatic impact on the school. The books were replaced with relevant, attractive volumes that appealed to both children and teachers. Mrs. Gerrard, at Carver Elementary, was also working cooperatively with the public librarian in her area. She regularly sought materials from the public library to supplement her school collection.

Teachers began to see that there were materials that they could use to teach their lessons. It strengthened the collaboration between media specialist and teachers. One teacher at King Elementary commented in a recent interview about the improvement in the school's collection,

Brand new-books - a variety! More series. Like with fifth grade, we have a theme....and this time we didn't have to go out to the public library to pull the books out ourselves...Also, in making the order she [media specialist] met with us to discuss what we would like to see, what we needed, in the media center...When I first got here we didn't have a lot of materials and now I feel good, as a result of whoever. And the books aren't just out-dated. (personal communication, November 13, 1996)

As part of staff development activities, media specialists and teaching teams participated in collection mapping (Loertscher, 1988) workshops. It gave them a framework to build collections based upon curricular needs of the school. The collaborative process was greatly enhanced through the addition of relevant resources. These findings should provide research support to promote building school resource collections for students; it should be a priority in all schools.

The building of the collection in the school brought with it a respected view of the media specialist. In the past, Mrs. Decker viewed her role as a person who was "keeper of the books." She spent a majority of her time on circulation tasks. Through increasing her role in developing a meaningful collection, teachers began to view her as a respected professional. In the third year of the study, Mrs. Decker reflected,

Like this morning, I had a teacher...come in, a second grade teacher, and she was just browsing around and she was really excited about the books in the reference section.... So, she said she was going to come in and let her students start doing some research, because I showed her all of the primary reference books that they would want to use. (personal communication, December 2, 1996)

Mrs. Gerrard collaboratively team planned units prior to Library Power. Recently, however, she noted that she has changed the way she collaborates with teachers. Now, her emphasis is to try to encourage teachers to take more ownership of the collaborative process. She does less management in the sessions and encourages teachers to take their own notes. She stated, "...if I look at the objectives...they never leave that first stage. And, it's somebody's role to get them to move to evaluate units. Synthesize and analyze; I'm trying to work on that." (personal communication, December 2, 1996) She said that she was discreetly trying to get teachers see what things they needed to add to units.

\section{Strengthening the Role of the Principal as Facilitator}

"Principals would do more lasting good for schools if they concentrated on building collaborative cultures rather than charging forcefully in with heavy agendas for change." (Fullan, 1992, p. 19) Developing a culture of collaborative relationships within the school is central to Library Power goals. Research (Haycock, 1995; Tallman, 1995) has focused on the role the principal fulfills in developing a collaborative school culture.

Collaboration among teachers and media specialists was a new concept for most participants in the study. Principals held divergent views on the roles they played in their schools to encourage collaborative relationships. Dr. Rebecca Smith viewed Mrs. Gerrard as a full teaching and planning partner within the school. She emphasized from the beginning of the study, 
This is a community. This school is a community that really nurtures me. There may be kind of a dynamic, of mutual support that all the constituencies provide for each other but it's a very energizing place, a place where I think we all feel and derive a lot of support from each other...And it's due to a lot of things, and one thing is that we are really able to use the heterogeneity of this community to create something that is not a competitive environment, which I think would kill us. But one where we all kind of hone our work collectively and not individually. (personal communication, June $15,1995)$

Dr. Mary Jones, in 1995, held the traditional view that leadership meant control and rigorous adherence to high standards. There was little evidence of shared vision among faculty members. In an interview during the first year, she discussed her role as principal:

I'll just say that I think I am the catalyst for everything that happens in this school. I think I set the tone with the staff by laying out a set of expectations at the beginning of the year, during the year, and then following through in terms of monitoring. (personal communication, June 15, 1995)

In a recent interview with Dr. Jones, researchers noted that her language indicated a more facilitative leadership role. When queried about the kind of administrative support she could give to her school, she responded,

One of the things that we are really trying to focus on is to have a set time for each grade level to meet with the media specialist to do their collaborative planning. Now, it really is a challenge to try to pull that together. But we are committed to doing that, because when they get together as a team all of them grow as they plan. Because, one person may have a great idea but when you put four people together that one idea can be expanded and broadened. It just gets better and better.... (personal communication, December 2, 1996)

Dr. Jones' language changed from "I" to "we," indicating a more facilitative approach to her leadership role in the school. According to Fullan (1992) principals are blinded by their visions when they feel that they have the vision and everyone must conform to their vision. When principals use proprietary language, it suggests ownership rather than a collective vision.

Mrs. Decker and the teachers noted the difference in the school culture during the three years of Library Power. Mrs. Decker expressed pleasure and exhibited a much stronger sense of motivation, because of Dr. Jones' obvious change to a more facilitative role. She noticed a visible change in Dr. Jones' attitude. "It makes me feel more motivated, more excited and it gave me a little more energy to really go after things and to really get things done and to be involved more with the teachers." (personal communication, December 2, 1996)

Although Carver Elementary was already involved in collaborative relationships at the outset of the study, Dr. Smith expressed that the school team grew dramatically throughout the Library Power program. They were now involved in greater collaborative relationships that included parents, multi-grade level planning with teachers, and the library media specialist. Business partners of the school and public librarians have also been a part of the planning process.

\section{Developing Learning-Centered Libraries}

One of the biggest challenges was to examine the ways in which the participant school library media centers met the needs of diverse student populations. In all school reform movements, the challenge is to prepare students to be information literate citizens for the twenty-first century. Research (Haycock, 1995; Lance, 1992) suggested that the media center impacts the learning environment of the school.

The researchers sought ways to improve student learning through the collaborative process engaged in by media specialists and teachers. Future high school graduates will have the ability to use information to acquire knowledge and become independent lifelong learners who contribute responsibly to the learning community (Stripling, 1996c). 
The assignments and research tasks that students engage in are an indicator of the level of thinking encouraged by teachers. Dr. Smith described that her school is moving to incorporate more authentic assessment into the curriculum. It has been difficult to develop rubrics to cover the types of standards of performance. They are encouraging teachers to build in alternative assessments into the collaboratively planned units. The planning sessions are qualitatively different than three years ago. "People have learned, I think, to have conversations with each other without getting stressed out about...this isn't the way I've always taught this..." (personal communication, December 2, 1996) Mrs. Gerrard stated that she is seeing different kinds of assignments "...because those are some things we talked about in the planning sessions....assignments shouldn't just be questions on a sheet of paper." (personal communication, December 2, 1996) Dr. Jones discussed the gradual change in assignments coming from teachers,...especially at the intermediate level, where they will give long-range assignments...that requires some research...that may take a week or longer...because it gets the children more focused in the use of the media center. (personal communication, December 2, 1996)

\section{Developing a School Culture to Sustain Reform}

Fullan (1996) posited that systemic reform depends on developing strategies to network and reculture schools. A media specialist can feel isolated in the school environment, because schools often have one media professional with little or no clerical assistance. The Library Power director mandated monthly networking meetings for media specialists, monthly breakfast meetings for principals, and regular staff development activities for school teams.

During the first year of the study, media specialists and principals argued that the monthly meetings placed heavy demands on their already strained time requirements for Library Power. By the third year, meeting requirements eased for principals, however, media specialists and principals noted that the shared experiences were valuable in implementing the goals of the program. When new schools joined the circle of participants, there was exchange of ideas and support for changes that were taking place in their schools. During one morning visit to Carver Elementary, Mrs. Gerrard received three phone calls for assistance in writing mini-grants for Library Power. As a senior respected member of the round one teams, many media specialists relied on her perspectives to help them with Library Power goals. Networking experiences facilitated the reculturing of schools through providing mutual support.

\section{Developing Community Involvement}

Sarason (1996) noted that schools do not exist in the encapsulated environment that educational reformers perceive as they try to implement change. Political laws and mandates are the most dramatic forces to apply pressure to schools. The socio-historical environment of the community impacts the schools causing resistance to change.

The National Library Power initiative included the community in reform efforts. From the outset of planning for the grant proposal, diverse stakeholders were included in the local process. At each Library Power school, business partners, parents and the community participated in planning, refurbishment, and implementing the goals of Library Power. The plans for community participation varied among the schools.

During the third year at Carver Elementary School, team planning sessions regularly included parents. The school had strong parental support through volunteer programs and the business partners contributed time and resources to the school.

King Elementary School had different needs. In a working class neighborhood, there were few parent volunteers. However, in a recent interview, Mrs. Decker discussed the long range impact she believed Library Power would have on the school. With a Library Power mini-grant, an outreach program was implemented. The community members were invited to attend classes to help adults earn their general education diplomas (GED's). As many as one hundred students attended classes, including families of English as a second language (ESOL) speakers. Three students recently passed the exams. 
At both schools parent resource collections were established in the media center to encourage interest and increased parent involvement. At King Elementary School, parents were invited to learn how to use computers through training provided by Project First, a grant that provided Library Power schools with technical computer assistance. The community involvement at both schools will encourage greater visibility and support for future goals.

\section{IMPLICATIONS}

Imbued with inspiration, Barker (Burdenuk, 1993) implored, "Vision without action is merely a dream. Action without vision just passes time. Vision with action can change the world." (p. 24) School reform requires leaders and a simple, clear vision of what can be achieved with a passion for excellence. Vision, a shared vision, is central to the success or failure of educational reform. The principal fosters development of that vision through collaboration for individuality (Brown, 1990, 1993; Fullan, 1992).

Dr. Smith, after the first year of the study, shared her views on becoming a Library Power school. She stated that their vision included everyone from the rookie teachers, to veteran teachers, to custodians and cafeteria staff, all focusing on "excellence in every area." Although the staff was not partial to status quo,

...there is always the danger in taking on too many new things that may take us off in different directions, but Library Power has really this year been the glue that brought into a coherent, almost focus, a number of things that we wanted to do better. And, I think the number one thing is the collaboration. (personal communication, June 15, 1995)

The changes (Tallman \& Tastad, 1995, 1996) that have been documented during Library Power have not come easily. Resistance to change, even when stakeholders agree on goals, results from the complex nature of schools. Neither administration from the top-down nor the bottom-up will result in systemic reform, however, addressing efforts at the bottom may help to achieve widespread improvements (Fullan, 1996).

The three years of Library Power in the school district have been greeted with applause. The challenge is to institutionalize the changes, creating benefits throughout the district. Extensive staff development opportunities have been provided to non-Library Power schools and additional grants are being solicited by the local education fund to implement systemic reform.

The researchers (Tallman \& Tastad, 1995) recommended that increasing control of the program be assumed by the school district's library media coordinator, lessening the outside role of the Library Power director. Researchers (Fullen, 1996; Sarason, 1996) posited that long term success of educational reform is dependent on ownership and personal commitment to ensure change. The greater the collaboration and consensus among stakeholders, the greater the commitment to achieve educational reform (Sarason, 1996).

A significant implication of the study is that higher education must prepare media specialists, teachers, and administrators to be collaborators promoting student learning. Media education programs have taught preservice school library media specialists that collaboration will ensure integration of the media center into the total school. Our research has informed us that collaboration is difficult in a school culture where individuals work in isolation (Haycock, 1995).

The vision of Library Power to increase collaboration among teachers, administrators, media specialists, parents, and the community is a vision of improved student learning. The library media specialist and the school library media program are pivotally situated to serve as a catalysts for reform through facilitating curriculum integration of information literacy skills.

\section{REFERENCES}

American Association of School Librarians. (1995). National Library Power Program. [Brochure]. Chicago: American Association of School Librarians.

Barron, D., \& Bergen, T. J. (1992). Information power: The restructured school library for the nineties. Phi Delta Kappan, 73(7), 521-525. 
Breivik, P. S. (1992). Education for the information age. New Directions for Higher Education, 78, 513.

Brown, J. (1990). Navigating the 90's-The teacher-librarian as change agent. Emergency Librarian, 18(1), 19-28.

Brown, J. (1993). Leadership for school improvement. Emergency Librarian, 20(3), 8-20.

Burdenuk, G. (1993). Vision and the school library resource center. Emergency Librarian, 20(3), 2224.

Fullan, M. G. (1992). Visions that blind. Educational Leadership, 49(5), 19-22.

Fullan, M. G. (1996). Turning systemic thinking on its head. Phi Delta Kappan, 77(6), 420-23.

Glaser, B., \& Strauss, A. (1967). The discovery of grounded theory. New York: Aldine.

Glasser, W. (1992). The quality school: Managing students without coercion (2nd ed.). New York: HarperPerennial.

Haycock, K. (1995). Research in teacher-librarianship and the institutionalization of change. School Library Media Quarterly, 23(4), 227-233.

Lance, K. C., Welbourn, L., \& Hamilton-Pennell, C. (1992). The impact of school library media centers on academic achievement. Denver, CO: Colorado Department of Education.

Lincoln, Y. S., \& Guba, E. G. (1985). Naturalistic inquiry. Newbury Park, CA: Sage.

Loertscher, D. V. (1988). Taxonomies of the school library media program. Englewood, CO: Libraries Unlimited.

Loertscher, D. V. (1988). Collection mapping and collection development. In W. A. Murray, M. Messervey, \& B. Dobbs (Eds.), Measures of excellence for school library media centers (pp. 40-51). Englewood, CO: Libraries Unlimited.

Patton, M. Q. (1990). Qualitative evaluation and research methods (2nd ed.). Newbury Park, CA: Sage.

Pitts, J. (1994). Personal understandings and mental models of information: A qualitative study of factors association with the information seeking and use of adolescents. Doctoral dissertation, Florida State University.

Pitts, J. (McGregor, J. H., \& Stripling, B. K., Eds.). (1995). The 1993-94 AASL/Highsmith research award study: Mental models of information. School Library Media Quarterly, 23(1), 177-84.

Sadowski, M. (1994). The power to grow: Success stories from the National Library Power Program. School Library Journal, 40(7), 30-35.

Sarason, S. B. (1996). Revisiting "The culture of the school and the problem of change." New York: Teachers College.

Stripling, B. K. (1996a). Information literacy standards for student learning. AASL Hotline/Connections, 4(1), 2-3.

Stripling, B. K. (1996b). President's message: Learning-centered libraries-A vision for the future. AASL Hotline/Connections, 4(1), 1.

Stripling, B. K. (1996c). Quality in school library media programs: Focus on learning. Library Trends, 44(3), 631-56.

Tallman, J. (1995). Curriculum consultation: Strengthening activity through multiple-context area units. School Library Media Quarterly, 24(1), 27-33.

Tallman, J., \& Tastad, S. A. (1995). Annual report of the Library Power program. Unpublished manuscript.

Tallman, J., \& Tastad, S. A. (1996). Using qualitative methodology to document the Library Power reform movement in school library media centers. Proceedings of the 1996 conference on qualitative research in education: Improvisations and deep structures: Alternative forms of data representation. [On-line]. Available: www.coe.uga.edu/quiq/Tallman\&Tastad.html

Weingand, D. E. (1993). Grounded theory and qualitative methodology. IFLA Journal, 19(1), 17-26.

Weisburg, H., \& Toor, R. (1995). Resource-based instruction enters the 21st century: Creating a new curriculum. Emergency Librarian, 23(2), 8-1. 